\title{
RETROSPECTION \\ IN INTERPRETING AND TRANSLATION: \\ EXPLAINING THE PROCESS?
}

\author{
Birgitta Englund Dimitrova \\ Stockholm University (Sweden) \\ birgitta.englund@su.se \\ Elisabet Tiselius \\ Stockholm University (Sweden), University of Bergen (Norway) \\ e.tiselius@aiic.net
}

\begin{abstract}
Retrospection is one of the few research methods equally suitable for studying the processes involved in both translation and interpreting. At the first workshop on research methods in process-oriented research (Graz 2009), we presented the results of a pilot study of retrospection as a research method, published as Englund Dimitrova $\&$ Tiselius (2009). The study involved data from two groups (15 years of professional experience vs. no professional experience), each with $3+3$ subjects (interpreter subjects vs. translator subjects, all with Swedish as their L1). The source text was a 10-minute plenary speech in English from the European Parliament, interpreted simultaneously into Swedish. For the translation data, the translator subjects translated the original European Parliament transcript of the speech, 1,093 words, using Translog. After the task, subjects did immediate retrospection. The first analysis of the data indicated that a challenge when using retrospection is that subjects tend to report having forgotten about some of their processes.

In this paper we report an analysis of the process data in relation to the retrospective protocols. Our focus is on reported problems and the occurrences of problem indicators in the process. It was found that most reported problems are confirmed by the presence of problem indicators in the process. However, the majority of problem indicators found in the process do not correspond to any reported problem. Hence, the subjects' problem reports can only explain a limited number of the potential problems
\end{abstract}


in the process. The need for further research into retrospection as a research method in Translation Studies is pointed out.

\section{Resumen}

La retrospección es uno de los pocos métodos de investigación igualmente adecuados para estudiar los procesos de traducción y de interpretación. En el primer taller sobre métodos de investigación de procesos (Graz 2009), se presentaron los resultados de un estudio piloto sobre la retrospección com odo de investigación, publicado como Englund Dimitrova \& Tiselius ( 2009). Le udio incluía datos de dos grupos (15 años de experiencia profesional frente a inexperlencia profesional), cada uno con $3+3$ sujetos (intérpretes y traductores, todos con sueco como L1). El texto original era un discurso de 10 minutos en inglés del Parlamento Europeo, interpretado simultáneamente al sueco. Para la traducción, los sujetos traductores usaron la transcripción original del discurso, de 1.093 palabras, usando Translog. Tras la tarea, los sujetos efectuaron retrospección inmediata. El primer análisis de los datos indicó que un reto al usar la retrospección es que los sujetos tienden a informar que han olvidado algunos de sus procesos.

Este trabajo presenta un análisis de los datos del proceso en relación con los protocolos retrospectivos. Nuestra atención se ha centrado en contrastar los problemas declarados con las ocurrencias de indicadores de problemas en el proceso. Encontramos que la mayoría de los problemas declarados se confirman por la presencia de indicadores de problemas en el proceso. No obstante, la mayoría de los indicadores de problemas que se encontraron en el proceso no se corresponden con ningún problema declarado. Por lo tanto, los informes de problemas de los sujetos sólo pueden explicar un número limitado de los problemas potenciales del proceso. Ello apunta a la necesidad de seguir investigando la retrospección como método de investigación en los estudios de traducción.

Keywords: Process research. Retrospection. Protocol analysis. Interpreting. Translation.

Palabras clave: Investigación del proceso. Retrospección. Análisis de protocolos. Interpretación. Traducción.

Manuscript received on March 29, 2013 and accepted on September 25, 2013 


\section{Introduction}

Retrospection is a popular method for analyzing translation and interpreting processes through the participants' own reports. In retrospection, an introspective method from cognitive psychology, subjects give verbal reports of their own cognitive processes after having performed a given task. Retrospection is facilitated if the probed task was recent and short. A disadvantage of retrospection is that it generally does not allow complete recall of the information, especially in longer tasks, for instance, translation. For interpreting it is one of the few methods available for investigating the process from participants' reports. Retrospection has gained popularity as translation and interpreting research has become more interested in process studies (cf. Göpferich 2008, Hansen 2006 and Vik-Tuovinen 2002). Analyzing retrospective data may, however, not be as straightforward as it perhaps seems at first. The data is based on the participants' recall, and reports may be distorted for many different reasons.

The purpose of this study is to explore the validity of retrospective data by relating it to the process data. It is a relatively small study and the approach is explorative. It is based on an in-depth analysis of part of the translation/ interpreting, where retrospective data is related to process data. The data from interpreting subjects and translation subjects are compared, both in terms of retrospection and process.

\section{Retrospection}

Memory is crucial in interpreting and translation. Memory research commonly agrees on a division of memory into three parts: long-term memory, short-term memory and working memory (Cowan 2008). As Cowan (2008: 325) points out, however, there has been some confusion as to the difference between short-term memory and working memory, and some researchers have used the two concepts interchangeably. Although the difference is still not crystal clear, there seems to be consensus that short-term memory involves immediate response to and storage of different types of input, while working memory is involved when any type of activation of mental processes occurs 
(Jonsson \& Eklund 2012: 586). Applied to processing in interpreting and translating, it could be assumed that short-term memory is used to identify and retain an utterance or piece of text, while working memory is activated to identify meaning and processing it into a new utterance of piece of text. Both these memories work in an automatized mode, unless the process is stalled by a difficulty or a problem.

The memory of how that situation was solved, and of the situation as such, may enter into long-term memory, but not necessarily. Functional forgetting (Karlsen 2008:71) is important in this context, as the brain retains what is necessary for solving the task at hand. Since everything that surfaces cannot be retained in the long-term memory, what is no longer needed can be quickly forgotten. Some memories remain, though, for different reasons. Various introspective methods allow researchers to tap into subjects' memory. Concurrent introspection, or think-aloud protocols (TAPs), taps into subjects' working memory (Ericsson \& Simon 1993: xlix), and has been widely used in translation process research. ${ }^{1}$ Retrospection, on the other hand, is assumed to tap into subjects' long-term memory (Ericsson \& Simon 1993: 21); the retrospection is also cued in order to trigger the memory. Using a cue is not without disadvantages, however, since by triggering the memory we also risk installing false memories (Meade \& Roediger 2002). Despite certain challenges, retrospection is a popular method in interpreting process research, as concurrent introspection is impossible during the interpreting task (see, e.g., Bartłomiejczyk 2006 and Chang \& Schallert 2007). Vik-Tuovinen (2002), using a recording of the interpretings as cue, has described in detail how retrospection can be used when studying interpreting. Ivanova (1999) also used retrospection for studying the interpreting process, using transcripts of the original speech as cue.

Before describing the analysis further, it seems important to define what we mean by retrospection or retrospective interview in this context. In Englund Dimitrova \& Tiselius (2009), we described more in detail how retrospection is used in translation and interpreting. Within the context of this study, retrospection refers to an interview that takes place immediately after the task and where the only cue is a transcript of the original speech/text. From this cue, the participant reports about everything s/he remembers from the process. It is thus not cued by any questions from the interview leader or by the participant's own production. The immediacy is an important condition; Ericsson \& Simon (1993: xvi) remind us that a cognitive task can only be

1. See an overview in Göpferich (2008) and also Jääskeläinen (2010) for further references. 
accurately recalled if the task is no longer than 0.5 to $10 \mathrm{~s}$ and the retrospection is immediate. Compared to those figures, the task in this study is very long: nine minutes for the interpreters and about an hour for the translators. The immediacy condition was partly observed, however, by doing the retrospection immediately after task. It should also be pointed out that this type of retrospective interview only deals with the task at hand and not with other tasks, the participants' background or opinions, or suchlike.

Since the process data in this study was not made available to the participants in their retrospection, their recall is assumed to be taken from their long-term memory of the process, without being distorted by any new cognitive processes involved in viewing their writing process (for translators) or listening to their own interpretation (for interpreters). This also means that the retrospective reports can be related to the process data in an analysis aiming to answer two questions:

1. Are retrospective problem reports confirmed by indicators of problems in the process?

2. Are there problems in the process that are not reported retrospectively?

\section{Materials and methods}

The overall design of this study and its rationale is described in Englund Dimitrova \& Tiselius (2009).

\subsection{Participants}

The participants in this study are 12 in total, three students of translation and three students of interpreting, together with three professional translators and three professional interpreters. Table 1 shows the background of the participants.

\begin{tabular}{|l|c|c|c|c|c|}
\hline Subjects & Male & Female & $\begin{array}{c}\text { Years at } \\
\text { university }\end{array}$ & $\begin{array}{c}\text { Years of } \\
\text { experience }\end{array}$ & Age \\
\hline Translation students & 1 & 2 & $3-4$ & 0 & $\begin{array}{c}20-30(\mathrm{n}=2) \\
40-50(\mathrm{n}=1)\end{array}$ \\
\hline Interpreting students & 0 & 3 & $4-5$ & 0 & $20-30$ \\
\hline Translation professionals & 2 & 1 & $4-5$ & $15+$ & $40-60$ \\
\hline Interpreting professionals & 1 & 2 & $4-5$ & $25+$ & $50-60$ \\
\hline
\end{tabular}

Table 1. Subjects. 
The students were recruited at the Institute for Interpreting and Translation Studies, Stockholm University. They all had Swedish as Ll and were taking the introductory course to translation and interpreting. They did not have any previous experience of translation or interpreting. The professionals were recruited at the institutions of the European Union. They all belonged to the Swedish unit (i.e., interpreting or translating into Swedish) and were seasoned professionals who all had Swedish as L1.

\subsection{Materials}

\subsubsection{Elicitation material and method}

For the interpreting and translation task, an English speech (09:35 m) from the European Parliament was chosen. The speech was authentic but slightly manipulated to add difficulties in terms of numbers and terminology. It was re-recorded with an English speaker with Received Pronunciation. For the translation task, a transcription of the speech, with normalized orthography and punctuation, was used. The number of words was 1,093.

All the subjects interpreted or translated the speech into Swedish. The students performed their interpretation or translation tasks at the Institute for Interpreting and Translation Studies. The professional interpreters and translators performed their tasks at their work place, whether in an empty interpreting booth (interpreters) or at their office (translators). The interpreting subjects were first asked to interpret the speech simultaneously from an audio recording and then perform retrospection with a transcription of the speech as cue. The translation subjects were asked to imagine that they were working under time pressure and therefore perform the translation as swiftly, yet carefully, as possible. Translation subjects translated on a laptop computer with Translog installed on it. The text was presented one sentence at a time so as to prevent the subjects from going back and forth in the target text and thereby possibly blurring retrospection. When the subjects considered the target text corresponding to one source sentence finished, they hit the enter key and the next source-text sentence appeared on the screen. After finishing the translation, they were asked to do retrospection with a copy of the original text as cue. Both interpreting and translating subjects were given a short list of some names and English terms from the speech. This was the only aid permitted. 


\subsubsection{Analyzed material}

For the analysis in this study, two paragraphs from the source text were chosen, comprising a total of 11 sentences with 219 words, that is, about $20 \%$ of the text's total 1,093 words. This part of the speech is approximately two minutes long for interpreters, the first minute consisting of 105 words or 170 syllables, the second minute consisting of 114 words or 195 syllables. This text segment was chosen because it was part of the manipulation; some names and figures had been introduced to the speech and were assumed to constitute potential problems in the process, especially for the interpreters. Furthermore, it was clear from the coding of the full protocols (cf. Englund Dimitrova \& Tiselius 2009) that these two paragraphs elicited a number of comments from all participants. So we assumed it was a suitable excerpt to analyze in depth. A transcription of the excerpt can be found in the Appendix.

\subsection{Method}

The method used in this study can be characterized as qualitative, although some quantitative results will also be provided.

\subsubsection{Coding the retrospection protocols}

The retrospection was done in Swedish, the subjects' L1. In table 2, the examples are from the data of the present study and are given in English translation. The processing problems in the retrospective protocols were coded according to the model in Ivanova (1999; see also Englund Dimitrova $\&$ Tiselius 2009). Table 2 summarizes the kinds of processing problems identified in this model.

The coding scheme of Ivanova (1999; see also Englund Dimitrova \& Tiselius 2009) distinguishes three further categories: monitoring, with six sub-categories; strategies, with eight sub-categories; and macrostrategies, with five sub-categories. These are not part of the analysis reported in this paper and will therefore not be presented here. 


\begin{tabular}{|c|c|c|c|c|}
\hline \multicolumn{3}{|c|}{ Processing problems (PP) } & $\begin{array}{l}\text { Examples from } \\
\text { interpreters }\end{array}$ & $\begin{array}{l}\text { Examples from } \\
\text { translators }\end{array}$ \\
\hline \multirow{5}{*}{ 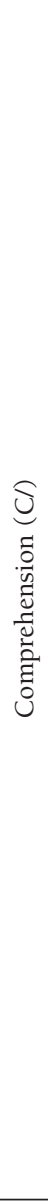 } & Perception (P) & Problems with hearing & \begin{tabular}{|l|} 
I didn't have time \\
to catch that it was \\
tobacco-related deaths. \\
(8/Amadeus)
\end{tabular} & $\begin{array}{l}\text { In our midst - now } \\
\text { that I read it, I did not } \\
\text { recognize it, so I don't } \\
\text { know. (9/Therese) } \\
\end{array}$ \\
\hline & $\begin{array}{l}\text { Lexical access in } \\
\text { SL (L) }\end{array}$ & $\begin{array}{l}\text { Failure to access } \\
\text { meaning of an SL chunk, } \\
\text { which has been identi- } \\
\text { fied as familiar }\end{array}$ & $\begin{array}{l}\text { I said TB but I'm not } \\
\text { sure what it means. (8/ } \\
\text { Amadeus) }\end{array}$ & $\begin{array}{l}\text { I don't know what } \\
\text { TB is, so then ... (9/ } \\
\text { Therese) }\end{array}$ \\
\hline & $\begin{array}{l}\text { Syntactic process- } \\
\text { ing (Syn) }\end{array}$ & $\begin{array}{l}\text { Failure to recognize } \\
\text { syntax patterns }\end{array}$ & $\begin{array}{l}\text { This is difficult, when } \\
\text { they start with that } \\
\text { they say "which", } \\
\text { which, like you start } \\
\text { having those subordi- } \\
\text { nate phrases and so } \\
\text { on, that is difficult. } \\
\text { (15/Amadeus) }\end{array}$ & $\begin{array}{l}\text { Or maybe the whole } \\
\text { sentence was a little } \\
\text { bit complicated, that } \\
\text { you had to - change } \\
\text { around a little bit. (2/ } \\
\text { Therese) }\end{array}$ \\
\hline & $\begin{array}{l}\text { Text integration } \\
\text { (TC/integ/) }\end{array}$ & $\begin{array}{l}\text { Difficulties in con- } \\
\text { structing a coherent } \\
\text { representation for SL } \\
\text { chunks }\end{array}$ & $\begin{array}{l}\text { It's like you understand } \\
\text { what it's all about, } \\
\text { but you miss certain } \\
\text { details. (21-22/ } \\
\text { Amadeus) }\end{array}$ & $\begin{array}{l}\text { I didn't know that } \\
\text { "unsafe" - what they } \\
\text { were referring to, if it } \\
\text { is the cigarettes that } \\
\text { are dangerous or that, } \\
\text { well ... (26/Therese) }\end{array}$ \\
\hline & $\begin{array}{l}\text { Text comprehen- } \\
\text { sion (TC/bgkn) }\end{array}$ & $\begin{array}{l}\text { Comprehension diffi- } \\
\text { culties due to lack of } \\
\text { background knowledge }\end{array}$ & $\begin{array}{l}\text { Yes, "community", } \\
\text { again I became, like, } \\
\text { confused over what is } \\
\text { com- which commu- } \\
\text { nity ... (47/Amadeus) }\end{array}$ & $\begin{array}{l}\text { And I thought, as } \\
\text { I read "framework } \\
\text { convention", I thought } \\
\text { that it was some kind } \\
\text { of meeting or almost } \\
\text { conference. But then } \\
\text { I started thinking, } \\
\text { convention, that is } \\
\text { more like - it's about } \\
\text { something else and } \\
\text { then maybe "ongoing" } \\
\text { isn't the right word. } \\
\text { (47/Therese) }\end{array}$ \\
\hline \multirow{2}{*}{ 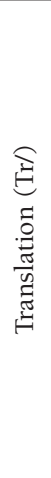 } & TL retrieval (TLr) & $\begin{array}{l}\text { Problems in rendering an } \\
\text { SL chunk in TL }\end{array}$ & $\begin{array}{l}\text { I got stuck in this, that } \\
\text { is "I must here com- } \\
\text { pliment", you know, } \\
\text { I thought, "Oh, how } \\
\text { should you put that?" } \\
\text { (10/Amadeus) }\end{array}$ & $\begin{array}{l}\text { "Public health" I don't } \\
\text { know - I didn't write } \\
\text { folkhälsan [public } \\
\text { health] I think - well, } \\
\text { anyway, I'm a bit } \\
\text { uncertain of how it } \\
\text { should be translated. } \\
\text { (3/Therese) } \\
\end{array}$ \\
\hline & Equivalent (eqv) & $\begin{array}{l}\text { Problems in selecting an } \\
\text { appropriate equivalent } \\
\text { when there is a choice }\end{array}$ & $\begin{array}{l}\text { I was thinking about } \\
\text { whatever that is called } \\
\text { in Swedish, I consid- } \\
\text { ered "guidelines" or } \\
\text { "descriptions". (37/ } \\
\text { Amadeus) }\end{array}$ & $\begin{array}{l}\text { And a couple of times } \\
\text { I hesitated - "tobacco } \\
\text { products", if it was bet- } \\
\text { ter to write "tobacco } \\
\text { products" or "tobacco } \\
\text { goods". (35/Therese) }\end{array}$ \\
\hline
\end{tabular}




\begin{tabular}{|c|c|c|c|c|}
\hline 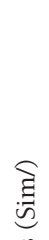 & (SL, TL) & $\begin{array}{l}\text { Problems due to high SL } \\
\text { input rate in relation to } \\
\text { interpreter's own output } \\
\text { rate }\end{array}$ & $\begin{array}{l}\text { Then there were too } \\
\text { many words, sort of, } \\
\text { like terms, "tobacco } \\
\text { advertising", "spon- } \\
\text { sorship", so I don't } \\
\text { know what I said. (45/ } \\
\text { Amadeus) }\end{array}$ & $\begin{array}{l}\text { Since I didn't want to } \\
\text { take too much time, } \\
\text { I think that I did it } \\
\text { fairly simply. } \\
\text { (31/Therese) }\end{array}$ \\
\hline 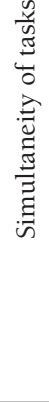 & $\begin{array}{l}\text { TL delays } \quad \text { TL } \\
\text { delays })\end{array}$ & $\begin{array}{l}\text { Delays in TL product due } \\
\text { to translation }\end{array}$ & $\begin{array}{l}\text { You know, I heard } \\
\text { this, but I didn't get it } \\
\text { out, everything that } \\
\text { is written here. It was } \\
\text { really difficult to, you } \\
\text { know, use these two } \\
\text { processes at the same } \\
\text { time, to listen and } \\
\text { understand and then } \\
\text { speak, it was like a } \\
\text { catch or an obstacle. } \\
\text { (10/Amadeus) }\end{array}$ & $\begin{array}{l}\text { And that is such a } \\
\text { thing where you could } \\
\text { have come up with } \\
\text { something better, if } \\
\text { you had reflected some } \\
\text { more on it. (9/Therese) }\end{array}$ \\
\hline
\end{tabular}

Table 2. Processing problems. Classification according to Ivanova (1999); the examples, drawn from the data in the present study, are given in English translation; the numbers refer to the sentence; names have been changed.

\subsubsection{Identification of problem indicators in the process data}

In order to identify possible problem indicators in the process data, we departed from the model of primary and secondary problem indicators in Krings (1986: 121ff.). However, this model was developed to account for another type of data, TAPs, and with the subjects handwriting their target text on paper. Furthermore, the indicators are of three different types: content of participants' verbalizations (nos. 1, 7 and 8), speech characteristics of participants' verbalizations (nos. 9-10), and observable behavior related to the translation process (nos. 2-6). Indicator 11 is of a mixed type, comprising both content characteristics (Krings 1986: 305-307) and pauses, that is, speech characteristics (Krings 1986: 308). Not all indicators were relevant for our data: content was instead coded in the categories from Ivanova (1999), and some behavior was not found due to differences in the research design. Indicators 1, 2 and 7 are potentially identifiable in the recorded interpreting data through various slips of the tongue, but are not found in our data. Table 3 shows the indicators presumed relevant for our different types of data.

In Krings' model, the first three indicators are considered primary, and the rest are secondary. A problem is identified through the existence of at least one primary or at least two secondary indicators. For the interpreting data, we assume that other indicators may also be relevant, such as speech 
disfluencies. Change in breathing patterns is also a possible problem indicator but was excluded from the analysis because of the categorization difficulties. For interpreting data, relevant process indicators are as follows:

1. A pause within a sentence, immediately preceding or following after a word/expression mentioned in a problem report. Not included are sentence-initial pauses, which we assume to be due to source sentence reading and planning, or sentence-final pauses, which we assume to be due to monitoring of the written target text (for pause length chosen, see section 4.1).

2. Revisions (not including the correction of typos).

3. A combination of 1 and 2 .

For interpreting data relevant process indicators are as follows:

1. Unfilled pauses (for pause length chosen, see section 4.1).

2. Paralinguistic indicators: change of lag or speech rate; intonation; sighs.

3. Speech disfluencies: repairs, false starts, fillers.

4. Unfilled pauses in speech production (not including pauses related to waiting for the speaker to begin an utterance) combined with indicators 2 and 3 .

\begin{tabular}{|l|c|c|}
\hline Indicator/mode & $\begin{array}{c}\text { Computer logging } \\
\text { of writing process }\end{array}$ & $\begin{array}{c}\text { Recording of } \\
\text { interpretation }\end{array}$ \\
\hline $\begin{array}{l}\text { 1. Explicit or implicit problem identification } \\
\text { by participant }\end{array}$ & - & (yes) \\
\hline 2. Use of aids & - & (yes) \\
\hline $\begin{array}{l}\text { 3. Leaving a gap in the translated text/ } \\
\text { interpreted utterance }\end{array}$ & yes & yes \\
\hline $\begin{array}{l}\text { 4. Competing tentative translation equivalents } \\
\text { 5. Changes in the TT }\end{array}$ & yes & yes \\
\hline $\begin{array}{l}\text { 6. Underlinings in the ST } \\
\text { 7. Negative evaluation of the TT }\end{array}$ & - & - \\
\hline $\begin{array}{l}\text { 8. Metaproblematization } \\
\text { 9. Unfilled pauses longer than 3 seconds } \\
\text { for interpreting) }\end{array}$ & - & yes \\
\hline $\begin{array}{l}\text { 10. Paralinguistic indicators } \\
\text { 11. Lack of primary equivalent association }\end{array}$ & - & yes \\
\hline
\end{tabular}

Table 3. The relevance of Krings' problem indicators to the present study. 


\section{Analysis of translation and interpreting data}

\subsection{Analysis of process data in relation to problem reports}

In the first analysis we departed from the retrospection data, identifying all instances of reported problems, and checked the interpretings or the logging files for process indicators related to the problem reports. The purpose of this analysis is to check the reliability of the problem reports. We expect that all or most problem reports will be confirmed by the presence of one or more problem indicators in the process data; an exception could be if a participant reports a problem in connection with a word or expression that is found also at some other place in the text, and errs in where the problem actually occurred.

The data were analyzed according to the following procedure:

1. Coding of processing-problem categories, according to the Ivanova (1999) model.

2. Identification of problem indicators in the process data:

a. Translation: Revisions involving words/expressions mentioned in the retrospection as problematic;

b. Translation: Pause(s) immediately preceding or following the writing of words/ expressions mentioned in the retrospection as problematic;

c. Translation: Combination of points a and $b$.

d. Interpreting: Disfluencies related to the problem report.

e. Interpreting: Paralinguistic indicators related to the problem report.

f. Interpreting: Isolated unfilled pauses related to the problem report.

g. Interpreting: Combination of two or three of the indicators mentioned in points $\mathrm{d}$, e or $\mathrm{f}$.

Tables 4 and 5 present the figures for verbalized problems and problem indicators in the process in sentences $34-45$ for students and professional translators. Where deemed relevant, percentages are given in the tables in 4.1 and 4.2, for ease of comparison. 


\begin{tabular}{|l|c|l|l|l|l|}
\hline & $\begin{array}{c}\text { Reported } \\
\text { problems }\end{array}$ & $\begin{array}{c}\text { Indicator: } \\
\text { Revision }\end{array}$ & $\begin{array}{c}\text { Indicator: } \\
\text { Pause } \geq 5 \mathrm{~s}\end{array}$ & $\begin{array}{c}\text { Revision(s) } \\
\text { pause(s) }\end{array}$ & $\begin{array}{c}\text { No process } \\
\text { indicator }\end{array}$ \\
\hline Josephine/S & 4 & 0 & $1(25 \%)$ & $2(50 \%)$ & $1(25 \%)$ \\
\hline Felix/S & 14 & $1(7.1 \%)$ & $8(57.1 \%)$ & $2(14.3 \%)$ & $3(21.4 \%)$ \\
\hline Therese/S & 11 & $3(27.3 \%)$ & $6(54.5 \%)$ & $1(9.1 \%)$ & $1(9.1 \%)$ \\
\hline Total & 29 & $4(13.8 \%)$ & $15(51.8 \%)$ & $5(17.2 \%)$ & $5(17.2 \%)$ \\
\hline
\end{tabular}

Table 4. Reported problems and problem indicators in the process, translation students.

\begin{tabular}{|l|c|l|l|l|l|}
\hline & $\begin{array}{c}\text { Reported } \\
\text { problems }\end{array}$ & $\begin{array}{c}\text { Indicator: } \\
\text { Revision }\end{array}$ & $\begin{array}{c}\text { Indicator: } \\
\text { Pause } \geq 5 \mathrm{~s}\end{array}$ & $\begin{array}{c}\text { Revision(s) } \\
\text { pause(s) }\end{array}$ & $\begin{array}{c}\text { No process } \\
\text { indicator }\end{array}$ \\
\hline Oskar/P & 6 & $1(25 \%)$ & $4(50 \%)$ & 0 & $1(25 \%)$ \\
\hline Tintin/P & 4 & $2(50 \%)$ & 0 & $2(50 \%)$ & 0 \\
\hline Isak/P & 4 & $1(25 \%)$ & $1(25 \%)$ & $1(25 \%)$ & $1(25 \%)$ \\
\hline Total & 14 & $4(28.6 \%)$ & $5(35.7 \%)$ & $3(21.4 \%)$ & $2(14.3 \%)$ \\
\hline
\end{tabular}

Table 5. Reported problems and problem indicators in the process, professional translators.

The shortest pause length found in the Translog data that correlated with problem report (according to the operational definition in section 3.3) was five seconds, and this pause length was therefore chosen for further analysis.

Tables 6 and 7 show the figures for verbalized problems and problem indicators in the process in sentences $34-45$ for students and professional interpreters.

\begin{tabular}{|l|c|c|c|c|c|c|}
\hline & $\begin{array}{c}\text { Reported } \\
\text { problems }\end{array}$ & $\begin{array}{c}\text { Indicator: } \\
\text { Speech } \\
\text { disfluency }\end{array}$ & $\begin{array}{c}\text { Indicator: } \\
\text { Silent pause } \\
\geq 0.5 \mathrm{~s}\end{array}$ & $\begin{array}{c}\text { Indicator: } \\
\text { Paralinguistic }\end{array}$ & $\begin{array}{c}\text { Combination } \\
\text { of two or more } \\
\text { indicators }\end{array}$ & $\begin{array}{c}\text { No } \\
\text { process } \\
\text { indicator }\end{array}$ \\
\hline Amadeus/S & 5 & - & $1(20 \%)$ & - & $4(80 \%)$ & - \\
\hline Kajsa/S & 11 & $1(9.1 \%)$ & - & $2(18.2 \%)$ & $8(72.7 \%)$ & - \\
\hline Lisa/S & 4 & - & $2(50 \%)$ & - & $2(50 \%)$ & - \\
\hline Total & 20 & $1(5 \%)$ & $3(15 \%)$ & $2(10 \%)$ & $14(70 \%)$ & - \\
\hline
\end{tabular}

Table 6. Reported problems and problem indicators in the process, interpreting students. 


\begin{tabular}{|l|c|c|c|c|c|c|}
\hline & $\begin{array}{c}\text { Reported } \\
\text { problems }\end{array}$ & $\begin{array}{c}\text { Indicator: } \\
\text { Speech } \\
\text { disfluency }\end{array}$ & $\begin{array}{c}\text { Indicator: } \\
\text { Silent pause } \\
\geq 0.5 \mathrm{~s}\end{array}$ & $\begin{array}{c}\text { Indicator: } \\
\text { Paralinguistic }\end{array}$ & $\begin{array}{c}\text { Combination } \\
\text { of two or more } \\
\text { indicators }\end{array}$ & $\begin{array}{c}\text { No process } \\
\text { indicator }\end{array}$ \\
\hline Bettina/P & 7 & - & - & - & $7(100 \%)$ & - \\
\hline Folke/P & 3 & - & - & - & $3(100 \%)$ & - \\
\hline Malin/P & 3 & - & - & - & $1(33.3 \%)$ & $2(66.7 \%)$ \\
\hline Total & 13 & - & - & - & $11(85 \%)$ & $2(15 \%)$ \\
\hline
\end{tabular}

Table 7. Reported problems and problem indicators in the process, professional interpreters.

In the analysis, the classification of pauses is shorter for interpreters than for translators. Naturally, this is linked to the differences in speech process and writing process. The shortest pause length for interpreters in the transcript correlating with problem reports was 0.5 seconds for isolated pauses, and 0.2 seconds for pauses in combination with other indicators; these pause lengths were therefore chosen for further analysis.. Her, the pause length for interpreters was also divided into two categories. rre reason behind this goes back to the definition of pauses as evidence of cognitive effort in simultaneous interpreting that was first approached by Goldman-Eisler (1961); more recent work on pauses in simultaneous interpreting has been done by for example Cecot (2001) and Tóth (2011). Pauses are interruptions of the speech flow and can be filled or unfilled. Silent pauses and disfluencies have been studied in order to gain insight in the interpreter's cognitive processes as well as the disfluencies in relation to the source language speech (Tissi 2000). Bakti (2009) provides a thorough overview on studies of disfluencies. In our study, isolated pauses of $0.5 \mathrm{~s}$ and over were found in relation to reported problems. Pauses as short as $0.2 \mathrm{~s}$ combined with other disfluencies were also found in relation to problem reports. These values tally nicely with Tissi's typology from 2000.

As can be seen in tables 4 and 5, our expectations regarding the relation of problem indicators in the process to problem reports were not confirmed by the keystroke logging data, in the sense that the number of reported problems without the presence of problem indicators in the process was unexpectedly high, 5 out of 29 (17.2\%) for students and 2 out of 14 (14.3\%) for professionals.

For interpreting data (tables 6 and 7), the figures were more in accordance with our expectations, with only one interpreter reporting problems that had no problem indicators in the process. On the other hand, the tables also show that in both students' and professional interpreters' process data, the 
majority of the problem indicators occur in combination with one or more other indicators, and the number of isolated problem indicators is quite low.

\subsection{Analysis of process data not related to problem reports}

In the second analysis, we depart from process data. The purpose here is to check the completeness of the reports. The more problem indicators found that involve words/expressions not mentioned as problems in the retrospection, the less complete the retrospection is. We certainly expected that there would be some indicators of problems without any retrospection report.

Identification of problem indicators in the process data:

a. Translation: Revisions involving words/expressions not related to problem reports.

b. Translation: Pause(s) within the sentence, not immediately preceding or following after the writing of words/expressions related to problem reports.

c. Interpreting: Disfluencies not related to problem reports.

d. Interpreting: Paralinguistic indicators not related to problem reports.

e. Interpreting: Isolated unfilled pauses not related to problem reports.

f. Interpreting: Combination of two or three of the preceding points.

The pause length for the second analysis was determined by the first analysis (see section 4.1). It was established at 5 seconds for translation data and 0.5/0.2 for interpreting data, thus the same for all participants, instead of establishing a value individually determined. Tables 8 and 9 display the figures for problem indicators not related to problem reports in sentences 34-45 for translation students and professional translators.

\begin{tabular}{|l|c|c|}
\hline & Revision & Pause $\geq 5 \mathrm{~s}$ \\
\hline Josephine/S & 12 & 9 \\
\hline Felix/S & 5 & 9 \\
\hline Therese/S & 9 & 6 \\
\hline Total & 26 & 24 \\
\hline
\end{tabular}

Table 8. Problem indicators not related to problem reports, translation students. 


\begin{tabular}{|l|c|c|}
\hline & Revision & Pause $\geq 5 \mathrm{~s}$ \\
\hline Oskar/P & 4 & 2 \\
\hline Tintin/P & 12 & 0 \\
\hline Isak/P & 10 & 5 \\
\hline Total & 26 & 7 \\
\hline
\end{tabular}

Table 9. Problem indicators not related to problem reports, professional translators.

Tables 8 and 9 show that the translation data include quite a large number of problem indicators in the process that do not correspond to any problem report. The figures are higher for students than for professionals, but for both groups they are more than twice as high as the figures for problem indicators in the process related to reported problems (see tables 4 and 5).

Tables 10 and 11 give the figures for problem indicators not related to problem reports in sentences 34-45 for interpreting students and professional interpreters.

\begin{tabular}{|l|c|c|c|c|}
\hline & $\begin{array}{c}\text { Speech } \\
\text { disfluencies }\end{array}$ & ParaL & $\begin{array}{c}\text { Silent Pauses } \geq 0.2 \mathrm{~s} \\
\text { with other indicators }\end{array}$ & $\begin{array}{c}\text { Silent Pauses } \geq \\
0.5 \mathrm{~s}\end{array}$ \\
\hline Amadeus/S & 18 & 7 & 3 & 15 \\
\hline Kajsa/S & 12 & - & - & 4 \\
\hline Lisa/S & 9 & 3 & 2 & 12 \\
\hline Total & 39 & 10 & 5 & 31 \\
\hline
\end{tabular}

Table 10. Problem indicators not related to problem reports, interpreting students.

\begin{tabular}{|l|c|c|c|c|}
\hline & $\begin{array}{c}\text { Speech } \\
\text { disfluencies }\end{array}$ & ParaL & $\begin{array}{c}\text { Silent Pauses } \geq 0.2 \mathrm{~s} \text { with } \\
\text { other indicators }\end{array}$ & $\begin{array}{c}\text { Silent Pauses } \geq \\
0.5 \mathrm{~s}\end{array}$ \\
\hline Bettina/P & 12 & 1 & 2 & 3 \\
\hline Folke/P & 15 & 1 & 3 & 6 \\
\hline Malin/P & 9 & 1 & 3 & 6 \\
\hline Total & 36 & 3 & 8 & 15 \\
\hline
\end{tabular}

Table 11. Problem indicators not related to problem reports, professional interpreters.

Tables 10 and 11 show that in the interpreting data the number of problem indicators in the process not related to a problem report is about four times 
higher for both students and professionals compared to the problem indicators related to a problem report. Just as for translators, the figures are higher for students than for professionals (see tables 6 and 7 ).

\subsection{Verbal reports vs. problem indicators in the process}

The data from tables 4, 5, 8 and 9 for translators are brought together in table 12 to give an aggregated picture of the quantitative relation between verbal reports and problem indicators in the process. The same is done for interpreters by bringing together tables $6,7,10$ and 11 in table 13 .

\begin{tabular}{|l|c|c|c|c|}
\hline \multicolumn{1}{|c|}{ Translators } & $\begin{array}{c}\text { Verbal problem } \\
\text { report and related } \\
\text { process indicator }\end{array}$ & $\begin{array}{c}\text { Process } \\
\text { indicator only }\end{array}$ & $\begin{array}{c}\text { Verbal problem } \\
\text { report only }\end{array}$ & Total \\
\hline Students & $24(30.4 \%)$ & $50(63.3 \%)$ & $5(6.3 \%)$ & 79 \\
\hline Professionals & $12(25.5 \%)$ & $33(70.2 \%)$ & $2(4.3 \%)$ & 47 \\
\hline Total & $36(28.6 \%)$ & $83(65.9 \%)$ & $7(5.6 \%)$ & 126 \\
\hline
\end{tabular}

Table 12. Quantitative relation between verbal reports and problem indicators in the process, translation subjects.

\begin{tabular}{|l|c|c|c|c|}
\hline Interpreters & $\begin{array}{c}\text { Verbal problem } \\
\text { report and related } \\
\text { process indicator }\end{array}$ & $\begin{array}{c}\text { Process indicator } \\
\text { only }\end{array}$ & $\begin{array}{c}\text { Verbal problem } \\
\text { report only }\end{array}$ & Total \\
\hline Students & $19(18 \%)$ & $85(82 \%)$ & - & 104 \\
\hline Professionals & $11(14.7 \%)$ & $62(82.7 \%)$ & $2(2.6 \%)$ & 75 \\
\hline Total & $30(16.8 \%)$ & $147(82.1 \%)$ & $2(1.1 \%)$ & 179 \\
\hline
\end{tabular}

Table 13. Quantitative relation between verbal reports and problem indicators in the process, interpreting subjects.

These figures show quite clearly that, quantitatively, the predominant category is problem indicators in the process that are not related with any problem reports, and that this is particularly true for interpreters. For interpreters, there could of course be a carry-over effect, that is, that a problem occurred earlier in the performance, and was reported on and that the effects of this problem were carried over to the next segment. However, these process indicators occurred in segments that were not preceded by problem reports. The cases where the problem report and the problem indicator(s) coincide are around 29\% in the translation data and less than $20 \%$ in the interpreting data. 
We did not expect the retrospective protocols to account for all the problem indicators in the process, but we were not expecting to find such a relatively low degree of correspondence between the two types of data.

\subsection{Verbal problem report without problem indicator in the process}

Of special interest are the cases where subjects report a problem, but there is no problem indicator in the process data. Tables 4 and 5 show that this is not uncommon in the translation data, the share being $17.2 \%$ of the students' verbal reports and $14.3 \%$ of the professional translators' verbal reports. It is less frequent in the interpreting data: it was not found at all in the students' data, and in $15 \%$ of the professional interpreters' data. A closer inspection of the cases from the data shows that one reason for these results may lie in the operational definitions applied. Two examples will clarify this.

Professional translator Isak reports a problem in finding the Swedish equivalent of descriptors in the NP misleading product descriptors. He was concerned that descriptors might be a term, and if so, that the correct Swedish term should be found. However, as he was not allowed to search in termbanks (cf. section 3.2.2), he was unable to ascertain this and wrote the Swedish word beskrivningar ('descriptions'). In his logging, there is a pause of 5 seconds before starting to write the translation of the whole NP, but not immediately preceding the problematic item. This does not meet the operational definition of pauses in the analysis (cf. section 3.3) and has therefore not been included. A reasonable assumption is that the reported problem was indeed present and processed as part of the processing of the whole NP. In this case, thus, our operational definition of a process indicator is too restrictive. A similar case is student Therese, who reports a problem with finding the exact Swedish equivalent to the expression break even, seemingly without a confirming process indicator. There is, however, a 5-second pause in her logging, that occurs sentence-initially (before she starts to write the target text of the full phrase So to break even), so it has not been counted (see operational definitions in section 3.3).

The following examples are to some extent similar. In some cases, the reported problems concern words or expressions found towards the end of a long source text sentence. In such cases, the problems may very well have been processed together with earlier parts of that sentence, thus leaving no specific trace of a process indicator in direct connection with the problematic word. An example is student Josephine, who reports a problem regarding target language retrieval for the English cigarette terms light, low tar and ultras, that is, whether to keep them in their English form or not. No process 
indicator is found. Another example is student Felix, who reports a problem with how to express the adverbial extra in Swedish in "a smooth way", as he puts it. No process indicator according to operational definition in 3.3 was found, but the word occurs towards the end of a rather long sentence. Characteristic of all these cases is that they concern words or expressions that are not difficult to understand for the subjects—-the difficulty lies in choosing the Swedish equivalent.

For interpreting (tables 6 and 7), students do not have any reports that are not confirmed by indicators in their process. Among the interpreting professionals only one, Malin, reports a problem that is not confirmed by her process data. She reports not hearing double filtered, but also evaluates herself immediately and says that it can be accepted in a long list when the pace is fast. In the protocol there are no problem indicators in the process. The delivery is smooth, without longer pauses, false starts or repetitions. The only thing that could possibly indicate an increased processing effort is a slightly faster breathing. However, the breathing can be due to other factors than the perception issue, such as pace. This is what Malin actually says in her retrospection:

Just det, just det. Ja, det där hörde inte jag - 'double filtered' hörde jag inte. Men det är en sån grej som, som kan accepteras tycker jag i en snabb - om han säger någonting snabbt, så får du inte med allt. Det måste man acc- det får - det måste man acceptera själv. Att man inte kan få med allting.

[Right, right, yes, I did not hear that - I did not hear 'double filtered'. But that's the type of thing that can be accepted, I think, in a fast - if he says something fast, then you don't get everything. You have to acc- it has - you have to accept that yourself. That you cannot get everything.]

The fact that there is no process evidence, combined with the way she expresses herself, can be seen as an indication that there was no actual problem during the task, but rather something she realized retrospectively. At first it seems obvious that she reports on not hearing 'double filtered', but when analyzing it in light of the process, it becomes clear that she does not for example report "I realized there was something I didn't hear, but it was too fast so I had to leave it out" or something similar. The way she expresses herself rather indicates that, when reading the transcript, she understands that she left something out. It is, however, very difficult to identify that only from the retrospective protocol. A similar example from the translation data is when professional translator Oskar correctly reports having reproduced in his Swedish text the English phrase break even, saying that "it went too quickly". This utterance we classified as PP/Sim/SL.TL, that is, "problems due 
to high SL input rate in relation to interpreter's/translator's own output rate" (cf. Ivanova 1999), thus interpreting it as reflecting Oskar's problems with the (self-imposed) time pressure of the translation task. Oskar's utterance is ambiguous, however, and could also be understood as an implicit evaluation of his own work in retrospect, that is, that he (now) considers that he acted too quickly and should have thought more before writing.

\section{Discussion}

This analysis of a segment of our data showed that retrospective verbal problem reports relate only to a minor part of the potential problem indicators in the process, namely, less than one-fifth of the interpreting data and just above one-fourth of the translation data. This was an unexpectedly low figure. The low degree of reports may in part be due to the subjects, either because they had forgotten quite a few of the problems they actually had or because they chose not to report some of the problems they actually had and remembered, for example, due to fatigue. This is as expected from other studies on retrospection, as mentioned above in section 2 .

However, the results can also be due to aspects of the analysis of data. The coding system of the retrospective protocols does not allow for the coding of every utterance in the protocols; thus, it may fail to capture certain utterances that are actually indicative of problems. That is, the coding system may be too restrictive. On the other hand, in the analysis of the process data, we may have been too inclusive: what we have tentatively coded as problem indicators in the process should perhaps better be labeled more cautiously potential problem indicators. For instance, a pause within an utterance or (the writing of) a sentence can be due to other cognitive activities than problem solving. Thus, some pauses in the translation data are probably related to reading further on in the ST or evaluating the part of the TT sentence already written down, or in the case of interpreters, causes connected with natural speech production.

Although infrequent, verbal reports not corroborated by the process data (mainly found in the translation data) are of special interest and they were therefore analyzed separately. The analysis showed that the operational definition of process indicator in this study is so strict that it most probably does not allow for identification of all indicators of problem-solving processes, when seen in relation to problem reports connected with a specific word or expression. It could be argued that the operational definition applied here is incompatible with a view of translation that assumes that translators comprehend and translate not words in isolation, but rather larger chunks within a context. Still, as shown in the data analysis, problem reports tend in the 
majority of cases to have corresponding problem indicators in the immediate vicinity of the problematic word/expression, according to this operational definition. There were also two examples, one from the translation data and one from the interpreting data, where the possible ambiguities lying in the interpretation of the retrospective protocol were clearly highlighted, something that could distort the results.

Problem indicators related to the process are different between interpreters and translators, and the amount of problem indicators in the process in interpreted data is larger than in the translation data. This is not surprising as it reflects differences in the speech process versus the writing process.

\section{Conclusions}

It must be assumed that not all problems are verbalized in retrospective protocols and it is clear that, in particular for translators, not all verbalizations have a coinciding problem indicator in the process. Clearly, retrospective reports must be used with caution in research and it must be emphasized that they give only a part of the picture. An important question then concerns the representativeness of the reports in relation to the whole set of data: given the incompleteness of retrospective reports, can we still draw conclusions regarding for example the quantitative relations between different categories of verbalizations in different categories of subjects?

Ericsson \& Simon (1980: 247) say that verbal reports are a reliable source for investigating cognitive processes when they are carefully elicited and "interpreted with full understanding of the circumstances under which they were obtained". In the case of retrospection it should also be added that the researcher has to take precautions as to what instances the subject actually remembers, and what instances may be blurred by other confounding processes. Considering the data in our material, it may also be prudent to take possible lacunae in the verbal reports into consideration. With that in mind, it is possible to draw appropriate conclusions from the material.

It is thus important to continue investigating what conclusions can actually be drawn from retrospective data, in order to be as appropriate as possible in the analysis of such data. It is equally important that research is precise and exhaustive in reporting the use of retrospective data to allow the reader to fully understand how the collection, analysis and interpretation of the data were carried out. 


\section{References}

BAKTI, Maria. (2009) "Speech disfluencies in simultaneous interpretation." In: De Crom, Dies (ed.) 2009. Translation and the (trans)formation of identities. Selected Papers of the CETRA Research Seminar in Translation Studies 2008. Electronic version available at: <http://www.arts.kuleuven.be/cetra/papers/ files/bakti.pdf> on 11 October 2012.

BARTŁOMIEJCZYK, Magdalena. (2006) "Strategies of simultaneous interpreting and directionality." Interpreting: International Journal of Research \& Practice in Interpreting 8:2, pp. 149-174.

CECOT, Michela. (2001) "Pauses in simultaneous interpretation: A contrastive analysis of professional interpreters' performances." The Interpreters' Newsletter 11, pp. 63-85. Electronic version available at: <http://www.openstarts. units.it/dspace/handle/10077/2448> on 23 October 2013.

CHANG, Chia-Chien \& Diane L. Schallert. (2007) "The impact of directionality on Chinese/English simultaneous interpreting." Interpreting: International Journal of Research \& Practice in Interpreting 9:2, pp. 137-176.

COWAN, Nelson. (2008) "What are the differences between long-term, short-term, and working memory?" In: Sossin, Wayne S.; Jean-Claude Lacaille; Vincent F. Castellucci \& Sylvie Belleville (eds.) 2008. Progress in Brain Research 169: The Essence of Memory. Amsterdam: Elsevier, pp. 323-338.

Englund Dimitrova, Birgitta \& Elisabet Tiselius. (2009) "Exploring retrospection as a research method for studying the translation process and the interpreting process." In: Alves, Fábio; Susanne Göpferich \& Inger M. Mees (eds.) 2009. Methodology, Technology and Innovation in Translation Process Research. Copenhagen: Samfundslitteratur, pp. 109-134.

ERICSSON, Karl Anders \& Herbert Simon. ([1984] 1993). Protocol Analysis. Verbal Reports as Data. Revised edn. Cambridge, MA: Massachusetts Institute of Technology.

ERICSSON, Karl Anders \& Herbert Simon. (1980) "Verbal reports as data." Psychological Review 87:3, pp. 215-251.

GOLDMAN-EISLER, Frieda. (1961) "The predictability of words in context and the length of pauses in speech." Journal of Communication 11:2, pp. 95-99.

GÖPFERICH, Susanne. (2008. Translationsprozessforschung. Stand - Methoden Perspektiven. Tübingen: Narr.

HANSEN, Gyde. (2006) "Retrospection methods in translator training and translation research." Journal of Specialised Translation 5, pp. 2-41.

Ivanova, Adelina. (1999) Discourse Processing During Simultaneous Interpreting: An Expertise Approach. PhD dissertation, University of Cambridge. 
JONSSON, Håkan \& Robert Eklund. (2012) "Kognition och talbaserade människa-dator-gränssnitt.” In: Allwood, Jens \& Mikael Jensen (eds.) 2012. Kognitionsvetenskap. Lund: Studentlitteratur, pp. 583-594.

JÄÄSKElÄÄInEN, Rita. (2010) "Think-aloud Protocol.” In: Gamiber, Yves \& Luc van Doorslaer (eds.) 2010. Handbook of Translation Studies. Amsterdam: John Benjamins, pp. 371-373.

KARLSEN, Pål Johan. (2008) Hva er hukommelse. Oslo: Universitetsforlaget.

KRINGS, Hans Peter. (1986) Was in den Köpfen von Übersetzern vorgeht. Tübingen: Narr.

MEADE, Michelle \& Henry Roediger. (2002) "Explorations in the social contagion of memory." Memory \& Cognition 30:7, pp. 995-1009.

TISSI, Benedetta. (2000) "Silent pauses and disfluencies in simultaneous interpretation: A descriptive analysis". The Interpreters' Newsletter 10, pp. 103-128.

То́тH, Andrea. (2011) "Speech disfluencies in simultaneous interpreting: A mirror on cognitive processes". SKASE Journal of Translation and Interpretation 5:2, pp. 23-31.

VIK-TUOVINEN, Gun-Viol. (2002) "Retrospection as a method of studying the process of simultaneous interpreting." In: Garzone, Giuliana \& Maurizio Viezzi (eds.) 2002. Interpreting in the 21st Century. Amsterdam: John Benjamins, pp. 63-71.

\section{Appendix}

Analyzed part of the speech

34. As a result of an amendment from this Parliament on 24th July 1999, the introduction of colour photos on product warnings is to be introduced for the first time.

35. This will greatly increase their impact.

36. In recent years, research has shown the importance of avoiding misleading product descriptors on tobacco products, because such descriptors may mislead the consumer into believing that one product is safer than another.

37. This directive introduces a requirement not to use such misleading terms on tobacco products.

38. As such it aims to protect smokers and non-smokers alike from misleading and dangerous descriptors such as light, low tar, double filtered, ultras, etc. 
39. In a previous declaration to the Parliament, I undertook to consult tobacco experts.

40. Richard Peto, who is statistician and epidemiologist at Magdalena College of the University of Loughborough, reported that BAT, British American Tobacco, recently gave more than $£ 3$ million to sponsor Nottingham University.

41. Now, every cigarette sold makes a profit for the company of about $3 \mathrm{p}$.

42. To get its donation money back, which we have to assume BAT wants to do, it has to sell 100 million extra cigarettes.

43. Every million cigarettes causes about one death.

44. So to break even, they've got to sell enough cigarettes to cause about 100 deaths.

45. The money, incidentally, was given to fund a professorship in corporate responsibility.

\section{BIONOTES / NOTAS BIOGRÁFICAS}

Birgitta Englund Dimitrova holds a PhD in Slavic Linguistics and is Professor Emerita of Translation Studies at Stockholm University, Sweden. Her main research interests focus on cognition, bilingualism, and translation, as evidenced by her monograph Expertise and Explicitation in the Translation Process, published by John Benjamins in 2005. She has also published on the interaction in interpreter-mediated encounters, and on the translation of dialect in fiction. Her current research project, "The translator's individual space," investigates individual characteristics in the process and the target texts of very experienced translators working from more than one source language.

Address: Svartågatan 3, 12845 Bagarmossen, Sweden. Birgitta.Englund@su.se

Birgitta Englund Dimitrova es doctora en lenguas eslavas y catedrática emérita de Estudios de Traducción e Interpretación en la Universidad de Estocolmo. Sus principales intereses de investigación comprenden cognición, bilingüismo y traducción, como muestra su monografía Expertise and Explicitation in the Translation Process, publicada por John Benjamins en 2005. También ha publicado artículos sobre la interacción en encuentros mediados 
por intérpretes y sobre la traducción de dialectos en la literatura de ficción. En su proyecto de investigación actual, "El espacio individual del traductor", estudia características individuales en el proceso y los productos de traductores muy experimentados que trabajan desde más que un idioma de origen. Dirección: Svartågatan 3, 12845 Bagarmossen (Suecia). Birgitta.Englund@ su.se

Elisabet Tiselius holds a PhD in Translation Studies and is a lecturer of Translation Studies at Stockholm University, Sweden. Her main research interests are expertise in interpreting and interpreters' and translators' cognitive processes. Her dissertation dealt with expertise and deliberate practice of conference interpreters. Her current research project, "Children and Interpreting," deals with child language brokering, children's interpreting processes, and ethical aspects of child language brokering.

Address: Rörstrandsgatan 18, 11340 Stockholm, Sweden. e.tiselius@aiic.net

Elisabet Tiselius es doctora en Estudios de Traducción y profesora de traducción e interpretación en la Universidad de Estocolmo. Sus principales intereses de investigación comprenden la interpretación y los procesos cognitivos de intérpretes y traductores. Su tesis doctoral trataba de la pericia (conocimiento experto) y la práctica deliberada en intérpretes de conferencias. Su proyecto de investigación actual, "Los niños en la interpretación", aborda la mediación lingüística efectuada por niños y sus aspectos éticos, los procesos de interpretación con niños.

Dirección: Rörstrandsgatan 18, 11340 Stockholm (Suecia).e.tiselius@aiic.net 